\title{
OSEBNI ČLOVEŠKI KAPITAL ALI KDO BO PREŽIVLJAL FUNKCIONALNO NEPISMENE IN NEZAPOSLJIVE LJUDI
}

loveški in socialni kapital se vedno pogosteje omenjata. Posamezni avtorji jima dajejo različne poudarke, najpogosteje ju omenjajo v literaturi o menedžmentu. Obravnavajo zlasti upravljanje s človeškimi viri, glavni cilj pa je zagotavljanje kakovosti dela in povečanje kapitala, ki ga ustvarjajo zaposleni. Menedžer ima svoj pogled na človeške vire, navadno preozek glede na vsesplošen in velik pomen človeka (znanja, sposobnosti in osebnostnih lastnosti) v sodobni družbi. Pomen človeških virov se v sodobni družbi kaže še z drugih pomembnih vidikov. Sodobna tehnologija omogoča, da se proizvodi cenijo, dražijo se storitve. Dražijo se vsa tista dela ali izdelki, kjer tudi računalniško voden stroj ali robot ne moreta nadomestiti človeka. Moč neke družbe se $v$ informacijskem obdobju meri po tem, kako razvite ljudi ima. Človek ni več privesek stroju, kot je bil $v$ industrijskem obdobju, človek »iztrži« iz sodobne tehnologije lahko toliko, kolikor je sposoben. Meje dela in ustvarjanja so odvisne od človeka, ker sodobna tehnologija nudi vedno več novih možnosti, ki jih ljudje zmorejo izkoristiti ali pa tudi ne. Kaj bomo delali in od česa bomo živeli, nam določajo ljudje, ki jih imamo na razpolago v posameznem podjetju ali kraju. Meje dosežkov določa človek. Brez ustreznega človeškega kapitala ni prehoda od kvantitete proizvodnje $h$ kvaliteti proizvodnje in k novi kvaliteti življenja.

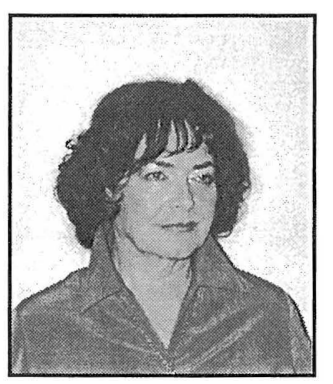

Izr. prof. dr. Ana Krajnc
O človeškem kapitalu govorimo s skupnostnega vidika pa tudi glede na posameznika. $S$ kakšnim človeškim kapitalom razpolaga posamezen človek? Merila človeškega kapitala pri osebi so: koliko znanja si je uspel nabrati, kakšna ima stališča in vrednote, kako ima razvite sposobnosti in kakšne ima osebnostne lastnosti ter koliko je učljiv in sposoben vsrkavati novosti. Po tem se ljudje med seboj zelo razlikujemo. Priner bom vzela iz odkritij sodobne nevrologije. Zabeležili so nekaj primerov, ko se je pri osebah po možganski poškodbi sprostil brezmejni spomin. Od dneva poškodbe so si za naslednjih 15 ali 30 let osebe zapomnile vse podrobnosti za vsak dan. Tak človek je bil sposoben za vsak datum povedati, kateri dan v tednu je bil, kakšno je bilo vreme ta dan itd. Ti in podobni primeri so nevrologom odkrivali, kakšne neslutene in neizkoriščene možnosti skrivajo človeški možgani. V praksi srečamo mlade, ki brez težav študirajo vzporedno na dveh fakultetah, pa tudi take, ki ne uspejo končati osnovne šole. Pri prvih se človeški kapital hitro kopiči, drugi so v razvoju že zelo zgodaj zakrneli. Še vedno raziskujejo, kje se skrivajo ključi človekove večje ali manjše učljivosti, in v prihodnje pričakujejo nova velika odkritja.

Vsak človek mora danes razpolagati z določenim človeškim kapitalom, če hoče preživeti 
in si zagotoviti neko socialno varnost. $V$ literaturi beremo o »osnovnih spretnostih « ali »osnovnih znanjih «(angl. basic skills) današnjega človeka. Iz več mednarodnih raziskav so povzeli, katera osnovna znanja naj bi danes imeli vsi ljudje pri roki. Znali naj bi se sporazumevati $z$ drugimi (komunicirati), (se) odločati, učiti se in uravnavati medosebne odnose. Naštete kompleksne spretnosti vsebujejo tako racionalne kot tudi čustvene komponente. Spretnosti odločanja potrebujejo veliko informacij in podatkov, miselno sklepanje ter primerno čustveno zalogo. Podobno se oblikujejo tudi ostale.

Kdo razpolaga z najnižjim človeškim kapitalom? Najniže izobraženi so funkcionalno nepismeni ljudje. Osebnostni razvoj je pri njih zakrnel zaradi dolgoletnega ponavljajočega se ozkega industrijskega dela. Danes pa se $s$ časom ne morejo več ujeti. Razvoja ne dohitevajo, zato se ne morejo več primerno odzivati na okolje. Niso več samozadostni in potrebujejo tujo pomoč. Starega sveta, v katerem so ustrezali, ni več, novega ne razumejo in se vanj ne morejo vključiti. Funkcionalno nepismenim ne manjka samo znanje, še bolj jih ovirajo nerazvite miselne funkcije, pomanjkanje intelektualne kondicije in samostojnosti, nerazviti interesi. Ostajajo pri lastnostih industrijskega delavca. Nagibajo se $k$ pasivnosti, posnemanju, konformizmu, težko se prilagajajo, ne prenašajo dvoumnih ali rizičnih situacij (teh je današnji svet poln), čakajo na pomoč od zgoraj, branijo se odgovornosti, dolgoročnih ciljev ne prenašajo. Na svet gledajo osebno, le z očmi svoje osebne usode. Manjka jim šef. Delujejo pod ravnijo za današnji čas potrebnih temeljnih lastnosti in sposobnosti, ki jih zahtevajo delodajalci, zato so nezaposljivi. Tudi za samozaposlitev niso dovolj razviti. Funkcionalno nepismene osebe so usedlina, ostanek industrijske družbe. "Kako, da sem bil nekoč toliko let dober za delodajalca, danes pa nisem več?", se spra- šujejo. Svojo socialno izločenost upravičeno doživljajo kot krivico, saj bi jim morali politiki še pravočasno zagotoviti nadaljnje izobraževanje in osebnostni razvoj, ker so vedeli, kaj nas v prihodnosti čaka. Funkcionalna nepismenost ni samo osebni, je tudi družbeni problem.

Zgled za to, kako povečati svoj človeški kapital, nam dajejo uspešni mladi ljudje. Za strokovno kariero in življenje ni več dovolj samo ena šola ali fakulteta. Če hoče nekdo povečati osebno zaposljivost, kombinira več izobraževalnih programov. Vpisuje se v programe še na drugih fakultetah (vzporedni študij), obiskuje razne seminarje na izobraževalnih ustanovah in se trudi, da pride do znanja in novih stališč tudi po neformalni poti. Več poti za pridobivanje znanja in osebnostni razvoj bi se med seboj pomešalo in razpršilo, če jih ne bi strukturiral in povezoval izdelan oseben izobraževalni in življenjski načrt. Človek mora vedeti, kateremu učenju bo dal prednost, zakaj se nekaj uči in svoje učenje osmisli v življenjskih ciljih. Mlad diplomant prava načrtuje svojo življenjsko pot. Srednjo šolo je opravljal $v$ tujini in mu je pri roki znanje nekaj tujih jezikov, med njimi tudi madžarščine. Zaradi svojih posebnih znanj se nagiba $k$ temu, da bi šel za sodnika v Prekmurje. Ljubezen do Prekmurja je razvil že kot otrok, ker je od tam doma njegov oče. Odkriva pa tudi nove možnosti. Slovenija bo vstopila v Evropsko unijo. Predvideva, da bodo povpraševali po specialistih za evropsko pravo. Na internetu odkrije prestižni študij evropskega prava v Londonu. Odloči se. Zbira potrebna finančna sredstva in odpotuje. Po dokončani specializaciji ga nihče ne pride iskat na dom, sam poišče potencialne točke za svojo zaposlitev. Dobi ustrezno mesto v Luksemburgu. Mika ga pisanje, obuja spomine na pokojnega očeta, ki je veliko objavljal, in vesel je, ko mu v pravniškem glasilu objavijo prve razprave. $\check{C}$ as je za družino. Partnerko »potegne« $v$ Luksemburg. 
Sedaj prilagajata njeno usposobljenost in zaposljivost. Sodobni svet se mu ne zdi težak in problematičen, ampak nasprotno poln izzivov in neštetih novih možnosti.

Osebna zaposljivost in stopnja človeškega kapitala sta sestavljenki več izobraževalnih in razvojnih vplivov. Rdeča nit razvoja je $v$ osebi sami. Osebnostni razvoj je kombinacija formalnega in neformalnega izobraževanja. Strokovna kariera ni več ločena od osebne začrtane življenjske poti. ¿̌e je človek sposoben sprejeti in predelati nastajajoče izzive in možnosti, potem ostaja $v$ srčiki družbe in je zaposljiv. V nasprotnem primeru je vedno bolj izrinjen na rob družbe.

Delodajalci pričakujejo »izdelane ljudi«, primerno razvite, opremljene $z$ znanjem, učljive in kompetentne za delo. Ne ukvarjajo se stem, kaj bo s funkcionalno nepismenimi. Tudi država se je zavila $v$ molk glede tega, ukvarja se z drugimi javnimi odgovornostmi in nadaljuje s selekcijskim (izločevalnim) šolskim sistemom. Obstoječi programi za odpravljanje funkcionalne nepismenosti so samo dekoracijski in spričo velikih potreb po razvoju ljudi ne pomenijo veliko.

Funkcionalno nepismeni znižlijejo človeški kapital neke družbe. Če je ta kritična masa prebivalstva prevelika, blokira ves razvoj. Funkcionalno nepismeni ni sposoben za samostojno učenje in si sam ne more pomagati, prav tako ne razpolaga $z$ ustreznim socialnim kapitalom (pravimi prijatelji in znanci), da bi se razvijal pod vplivom drugih ljudi in $v$ raznih življenjskih situacijah. Socialne stike ima zožene na najbližje sorodnike in sosede, v javnost ne vstopa.

Vprašanje, kdo bo preživljal funkcionalno nepismene prebivalce, ostane še naprej odprto. Zaposleni tožijo, da imajo preveč dela, drugi so brezposelni. Ali bodo sposobni in zapo- sljivi zmogli vsa bremena v družbi? Kako bo država v prihodnje dorekla izobraževalno in kulturno politiko?

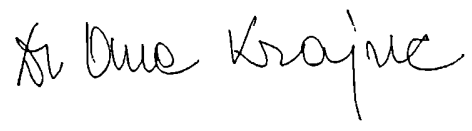

